\title{
Breeding Approaches for Sustainable Vegetable Production - A Review
}

\author{
N.A. Tamilselvi* and T. Arumugam \\ Department of Vegetable Crops, Horticultural College and Research Institute, Tamil Nadu \\ Agricultural University, Coimbatore-641 003, Tamil Nadu, India \\ *Corresponding author
}

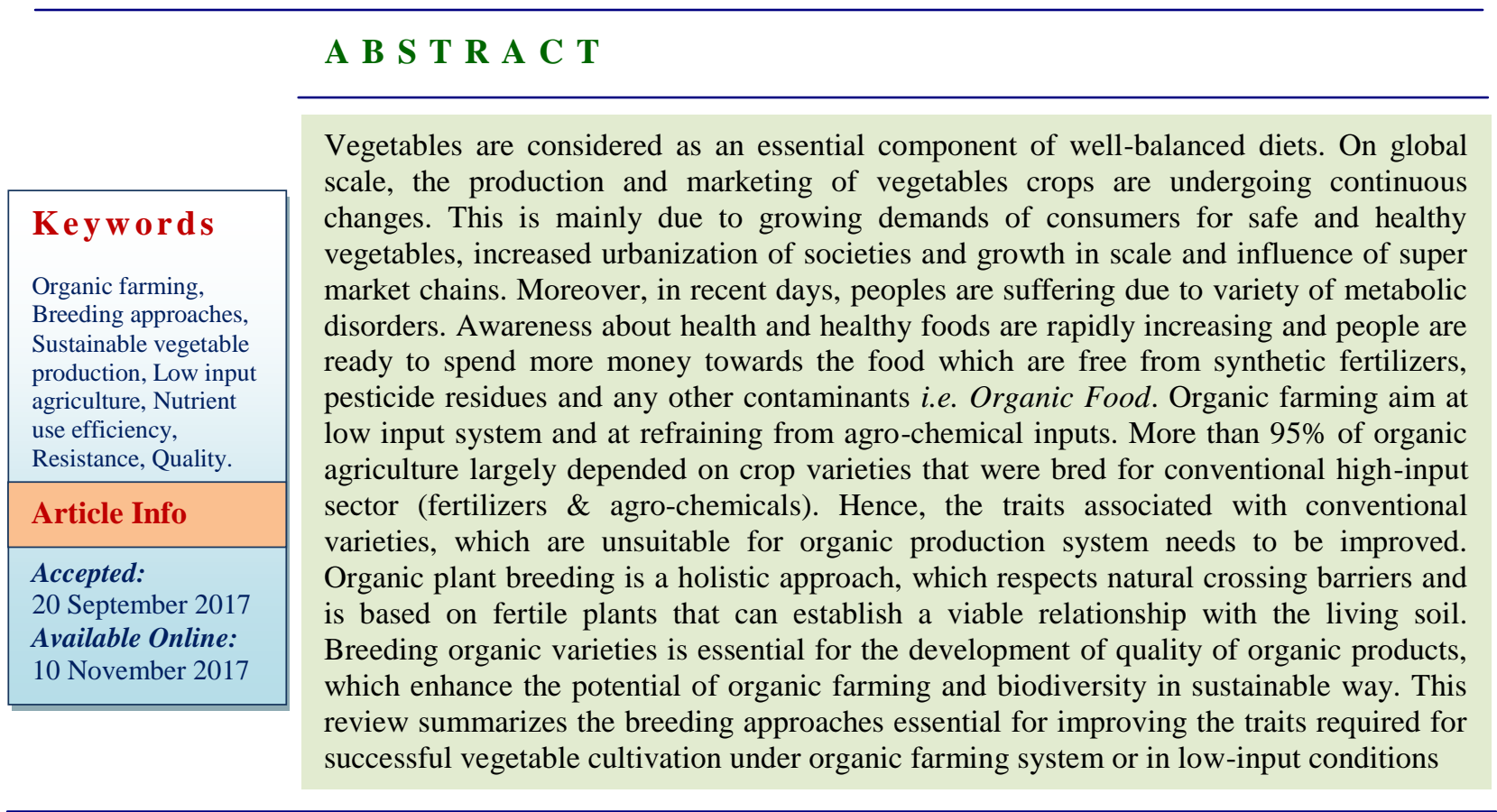

\section{Introduction}

Modern agriculture largely depends on the use of inputs such as chemical fertilizers, pesticides, herbicides and labour saving but energy intensive farm machinery. Application of these high input technologies undoubtedly increased the production. However, those high input agriculture degrades some of the natural resources on which this system rest. Beyond the adverse effect on soil productivity and environment quality, it does not guarantee sufficient food production in the next decades in a sustainable way. Hence, there is an urgent need to develop farming techniques which are sustainable from environment, production and socio economic point of view. In the recent days, agricultural community is setting its hopes on sustainable agriculture, which will maintain the cycles of inputs and ecosystem balance.

There are different concepts of sustainable agriculture that often referred as organic, alternative, ecological or low input agriculture. Off which, organic farming is the 
most widely recognized alternative farming system which gained social, political and scientific recognition for its contribution to sustainable agriculture. Organic agriculture is a production system, which avoids or largely excludes the use of synthetic fertilizers, pesticides, growth regulators and livestock feed additives. To the maximum extent feasible, it largely rely upon crop rotations, crop residues, animal manures, legumes, green manures, off farm organic wastes, mechanical cultivation, mineral bearing rocks and biological pest and disease control measures to maintain soil productivity and tilth to supply plant nutritions and to control insects, weeds and other pests (USDA Report, 1980).

\section{Current status}

The latest survey on certified organic agriculture worldwide shows 50.9 million hectare (FiBL statistics, 2015-16). On global scale, Organic agriculture is practiced in 172 countries by 2.4 million producers or farmers approximately and the countries with highest numbers of producers are India, Ethiopia and Mexico (FiBL statistics 2015-16 and Anonymous, 2017). In India, the total area under organic certification is 5.71 million hectare (2015-16). This includes 26\% cultivable area with 1.49 million hectare and rest $74 \%$ (4.22 million hectare) forest and wild area for collection of minor forest produces.

India produced around 1.35 million MT (2015-16) of certified organic products which includes all varieties of food products viz., Fruits, dry fruits, vegetables, spices, tea, coffee sugarcane, oil seeds, cereals, millets, cotton, pulses, medicinal plants etc., The production is not limited to the edible sector but also produces organic cotton fiber, functional food products etc., Among all the states, Madhya Pradesh has covered largest area under organic certification followed by Himachal Pradesh and Rajasthan. The total volume of export during 2015-16 was 263687 MT. The organic food export realization was around 298 million USD. Organic products are exported to European Union, USA, Canada, Switzerland, Korea, Australia, New Zealand, South East Asian countries, Middle East, South Africa etc., Oil seeds (50\%) lead among the products exported followed by processed food products (25\%), Cereals and Millets (17\%), Tea (2\%), Pulses (2\%), Spices $(1 \%)$, Dry fruits $(1 \%)$ and others (APEDA report, 2016).

\section{Reasons for development of varieties/ hybrids suitable for organic farming}

The characteristics of organic agricultural systems are their biodiversity at soil, crop, field, crop rotation or polyculture, landscape level and the greater focus on integration of crop and livestock production systems on the farm compared with conventional farming systems (Mader et al., 2002). Organic farmers have long depended on conventional variety and seed production, which requires high levels of artificial fertilizers and agrochemicals to obtain targeted yield. However, organic farming aims at a low input system and at refraining from agro-chemical inputs (Lammerts van Bueren, 2003).

To date, there are only few varieties that were specifically bred for organic and low-input systems in developed countries. It is estimated that more than $95 \%$ of organic agriculture is based on crop varieties that were bred for the conventional high-input sector with selection in conventional breeding programmes (Lammerts van Bueren et al., 2011). Recent studies have shown that such varieties lack important traits required under organic and low-input production conditions (Lammerts van Bueren et al., 2002; Murphy et al., 2007; Wolfe et al., 2008). 
A range of breeding goals desired for organic sector, such as yield, resistance to biotic and abiotic stress and sensory qualities demanded by consumers which do not differ from conventional breeding goals, but it is essential that such traits are expressed under low-input conditions (Lammerts van Bueren et al., 2011). Hence, development of genetic diversity focused crop breeding approaches may be essential to improve yield and quality parameters in foods from organic and lowinput farming systems, especially in the context of the challenges expected due to global climate change (Ostergard et al., 2009). Moreover, the worldwide standards of organic agriculture (OA) do not allow genetic engineering (GE) or any products derived from genetic engineering. The standards in $\mathrm{OA}$ are an expression of underlying principles of health, ecology, fairness and care (Nuijten et al., 2017).

Brandt et al., (2011) and Crowder and Reganold (2015) stated that organic farming systems produce lower yields compared to conventional agriculture. However, they are more profitable and environment friendly and deliver more nutritious fruits and vegetables that contain low to no chemical-synthetic pesticide residues compared with conventional farming (Reganold and Wachter, 2016). Ponti et al., (2012); Seufert et al., (2012) and Kniss et al., (2016) accounted an average yield gap of approximately $20 \%$ between conventional and organic agriculture. However, Ponisio et al., (2015) and Kniss et al., (2016) reported that the $20 \%$ yield gap does not count for all crops and all regions, as in some cases difference has not been noticed in some crops. Therefore, the future challenge is to further optimize the productivity of organic farming systems to overcome the average yield gap between conventional and organic agriculture. Another factor of limited yield under organic agriculture is the lack of cultivars adapted to low-input growing conditions without use of herbicides, pesticides and fungicides. Van Bruggen and Finckh (2016) stated that organic farmers loose potential yield due to lack of sufficient weed suppression, pest and disease resistance traits (e.g. onion against downey mildew and in potato against late blight).

It often takes 10 years or more from the initial inter-varietal crosses to develop a new crop variety. To realize the varietal improvements needed in organic farming in the coming decades, crosses between appropriate parental varieties have to be made now. Therefore it is essential to identify the primary limiting factors of existing varieties for organic production and target them in the breeding programmes for organic farming. In this circumstance, the main traits required for successful vegetable cultivation under organic farming or low-input conditions are described hereunder.

\section{Nutrient-use efficiency}

The greatest difference between organic and conventional systems relates to soil management practices used and processes in the rhizosphere (Baresel et al., 2008). Organic systems often rely on organic matter based fertilizer inputs and mineralization driven $\mathrm{N}$ and $\mathrm{P}$ supplies to crops. Macronutrient availability patterns during the growing period therefore differ significantly from those in conventional systems. Warman (1998) stated that organic crops often experience limited macronutrient $(\mathrm{N}$ and $\mathrm{P}$ ) availability especially during periods when soil temperatures and water availability reduce mineralization capacity by soil biota. However, regular organic matter inputs have shown to increase soil biological activity, biodiversity and mineralization capacity of the soil (Fliessbach et al., 2007). Przystalski et al., (2008) and Van Bruggen and Finckh (2016) reported that organic farmers often 
apply $50-80 \%$ of nitrogen through organic matter based fertilization compared to the amount of nitrogen in conventional farming systems. While the nitrogen of organic matter will slowly released and it also prevents nitrate leakage to surface and ground water. In addition, organic matter based fertilization have shown to suppress diseases (Ghorani et $a l ., 2008)$ and induce biochemical pathways in crops involved in pathogen defense and stress tolerance (Kumar et al., 2004). Concomitant to this finding, Van Bruggen and Finckh (2016) enumerated that limited nitrogen supply reduces too luxurious vegetative growth that could limit the pests (e.g., aphids) and foliar diseases (e.g., mildew) as in cereal production. From comparative studies between conventional and organic/reduced-input systems, Van Bruggen (1995) concluded that in organic or reduced input system, root diseases and pests are generally less of problem than foliar diseases, because foliar disease development is much more determined by climatic factors. Many root diseases can be eliminated by broad rotation in organic systems. Therefore, an essential element in organic farming systems is to gain and maintain soil fertility with an active soil life contributing to the nutrient availability, good soil structure and crop specific manuring for buffering and resistance to unbalanced plant growth.

In this context it is likely that organic systems require crop genotypes that are able to form active symbiotic relationships with beneficial organisms in the rhizosphere and thereby establish mechanisms that increase nutrientuse efficiency (e.g. vigorous root systems, ability to form active mycorrhizal associations, reduced root losses due to pathogens, ability to maintain a high mineralization activity in the rhizosphere via root exudates, increased rooting depth and associated ability to recover $\mathrm{N}$ leached from the top soil).
According to Dawson et al., (2008), nutrientuptake efficiency of plants can be improved by maintenance of photosynthesis under nutrient stress condition, nutrient uptake capacity, nutrient-utilization capacity and translocation efficiency will contribute to higher yield and quality under low input conditions. Therefore, adaptation of varieties to efficient nutrient use derived from slow nutrient releasing organic fertilizer is of special importance in organic farming, which is not addressed in conventional systems with no or less inorganic fertilizer. Nutrient-uptake efficiency of plants can be improved by plantgrowth promoting-rhizosphere (PGPR) bacterial communities (Gosling et al., 2006; Wissuwa et al., 2009) and arbuscular mycorrhizas (AMs) known as "rhizosphere competence". PGPR-bacteria promotes $\mathrm{N}$ uptake efficiency since they protect root systems against soil-borne pathogens attack (Cook, 2007), maintains efficient mineralization driven nutrient supplies to plant roots (Rengel and Marschner, 2005; Shaharoona et al., 2008) and support the establishment of active AM associations (Dawson et al., 2008). Similarly, Gosling et al., (2006) and Mader et al., (2000); Wissuwa et al., (2009), stated that AMs are essential for efficient phosphorus, micronutrient and water uptake of plants grown under organic farming and low-input conditions respectively.

Larkan et al., (2007) identified genes in tomato which has the ability to form mycorrhizal root symbiosis and Kumar et al., (2004) inferred that association of specific microorganisms on roots can influence gene expression in the plant. Greenwood et al., (2005 and 2006) and White (2007) studied Puse efficiency in B. oleracea and showed that there is genetic variation in this trait and that it is under quantitative control White (2007). Kage et al., (2003) reported that cauliflower varieties with proportionally more fine roots have shown more N-use efficiency. 
According to Kramer (1979) and Bertin and Gallais (2000) agronomic practices like fertilizer applications and environmental or climatic conditions like temperature, light intensity and soil moisture have a significant impact on nutrient-use efficiency (NUE). Hence, the crop plants should be selected within the context of different agronomic and climatic environments.

\section{Weed competition}

Weed control also remains a problem in many crop plants. However, weed management in row crops grown from transplants, including many Brassica and some Allium crops, tends to be less problematic than in these crops grown from seed. This is primarily due to more rapid development and associated competitiveness against weeds as well as the greater suitability of transplanted row crops for inter-row mechanical weeding methods (Lammerts van Bueren et al., 2011). Broccoli seedlings are small and may take longer time for germination and establishment than competing weeds. For organic production, broccoli varieties suitable for direct seeding should have rapid emergence and growth habit and shade neighboring weeds. Since, B oleracea has great diversity of cultivated morphological types, sufficient genetic variation should be present in these species for development of varieties with more weed competition under organic cultivation.

Allelopathy is another potentially important weed suppression trait that has received little attention in recent years. Fay and Duke (1977) and $\mathrm{Wu}$ et al.,(1999) stated that allelopathy is a chemical process where plants provide themselves with a competitive advantage due to direct or indirect effect on germination, growth or development of neighbouring plants. Hence, allelopathic potential of crop germplasm should be evaluated initially for development of varieties with allelopathic activity. Wu et al., (1999) suggested that identification of varieties with high allelopathic activity and transfer of such characteristic into modern varieties could restore an important trait that has inadvertently been lost during the process of selection for higher yields.

In Brassicaceae, glucosinolate breakdown products have weed and pathogen suppressive effects (Lammerts van Bueren et al., 2011). Myrosinase catalyzes the conversion of glucosinolates to isothiocyanates and related compounds but is not released until plant tissue disruption (Vaughn and Boydston, 1997). The effect has been most clearly demonstrated in crops following ploughing under a cruciferous green manure crop. Jimenezosornio and Gliessman (1987) and Itulya and Aguyoh (1998) examined allelopathic effect of Brassica crops on weeds and observed no significant effect. It is unlikely that weed suppression through allelopathy could be directly used in broccoli, but varieties bred with increased glucosinolate levels in vegetative tissues could be part of a long-term weed control strategy in crop rotations (Lammerts van Bueren et al., 2011).

\section{Tolerance/ resistance to mechanical weed control}

Selection of genotypes with tolerance or resistance to mechanical weed control (especially tine weeders) also becoming an efficient component of breeding strategies for weed competitiveness. Especially in reduced tillage systems, mechanical weed control is applied more frequently due to higher weed pressure. Tillage systems have a direct effect on soil carbon balances, soil organic matter, rooting depths and loss of top soil by wind and water erosion. Types of tillage systems include no tillage, minimum tillage and deep ploughing. No tillage systems are dependent upon herbicides, so that soil erosion and 
carbon losses are reduced. However, in reduced or minimum tillage systems, herbicide-free protocols are feasible (Berner et al., 2008; Krauss et al., 2010) and could be further implemented into organic farming if varieties have increased competitiveness and/or resistance to mechanical weed control.

Rao and Dao (1994); Weisz and Bowman (1999) and Carr et al., (2003) observed varieties suitable for reduced tillage and no tillage systems are also perform well under conventional tillage systems and inferred that tillage system does not need to play a role in varietal selection.

According to Donner and Osman (2006) and Murphy et al., (2008) mechanical weed control is usually done with tine weeders early in the season, supplemented in some regions by inter-row cultivation. Therefore, the ability to tolerate damage and/or rapid recovery following mechanical weed treatments is an important trait for varieties used in organic and low input systems.

\section{Resistance to major seed borne diseases}

Resistance to seed borne diseases in organic seed production is an important issue as few seed treatments are permitted for use under organic farming standards. According to Hetrick et al., (1995); Rengel and Marschner (2005) and Wissuwa et al., (2009) resistance to seed-borne diseases is an important trait because root systems are required for crops to express their genetic potential for nutrient-use efficiency and yield. Seed borne diseases of tomato include tomato mosaic virus (ToMV), bacterial speck and bacterial spot (caused by Pseudomonas syringae and Xanthomonas campestris pv. vesicatoria, respectively) and fungal pathogens such as Clavibacter michiganensis. ToMV become a major threat to conventional and organic tomato production, whereas bacterial and fungal diseases are more serious problem in organic systems restrictions in the use of fungicides and antibiotics (other than sulphur and copper based products). The two basic strategies to control seed-borne diseases in tomato are: (1) the use of seed treatments (e.g. antagonistic micro-organisms, compost extracts, fermentation, acids and acidified nitrite) and hot water treatment and/or (2) use of resistant varieties.

ToMV become a major yield limiting constrain in greenhouse grown tomatoes because the virus is stable and easily spreads through handling. Seed treatment to inactivate the virus does not work well, particularly if the virus is present in the endosperm of the seed. Therefore, the uses of resistant varieties become a viable option for organic production systems. The ToMV resistance gene 'Tm-22' has been derived from Solanum peruvianum through embryo rescue technique and incorporated into commercial varieties (Hall, 1980). Another resistance gene ' $\mathrm{Tm}-1$ ' from S. habrochaites provides resistance against the predominant strain of ToMV which can be incorporated into commercial varieties through conventional crossing technique (Pelham, 1966). Similarly, bacterial speck and bacterial spot resistance sources are available in tomato germplasm and should be incorporated into commercial varieties bred for organic production system. Bacterial wilt (Rastonia solanacearum) is also major seed borne problem in tomato and Indian Institute of Horticultural Research, Bangalore released a bacterial wilt resistant varieties viz., Arka Abha (BWR-1) and Arka Alok (BWR-5) which could be used for organic cultivation.

The major seed-borne disease of broccoli is black rot (caused by Xanthomonas campestris pv campestris). As in tomato, it can be controlled by seed treatment with antibiotics and copper based products in conventional production systems. However, the best option 
for organic production would be use of resistance varieties. Tonguc and Griffiths (2004) found incomplete resistance in $B$. oleracea, but more complete forms of resistance have been identified in $B$. napus and $B$. carinata. They also inferred that early attempts to introduce resistance from $B$. carinata into $B$. oleracea were made using somatic hybridization and recently in vitro embryo culture was used to introgress resistance.

\section{Disease resistance}

Tolerance to diseases that may cause injuries and are likely to affect plant health and quality is crucial for minimizing the gap between yield potential and actual yield. This applies to conventional high-input as well as to low-input or organic farming. Stone et al., (2004) stated that Fusarium wilt (Fusarium oxysporum f. sp. lycopersici) and Verticillium wilt (Verticillium dahlia) of tomato may be of less concern in organic production systems compared with their impact on conventional ones due to the suppressive effects of organic matter based fertilization regimes. On the otherhand, viral diseases such as Tomato mosaic virus (ToMV) and tomato spotted wilt virus (TSWV) are more universal occur regionally and TSWV become independent of production system. Whereas late blight (Phytophthora infestans) is of less concern in conventional systems due to greater choice and efficacy of fungicides available compared with organic systems, where only protective copper fungicides can be used. Several sources of resistance for late blight are known (Myers, 2009) which can be used for development of late blight resistance varieties in tomato intended for organic production systems (Horneburg and Becker, 2008; Myers, 2009).

Although a number of diseases may affect broccoli regionally, head rot is a complex of soft rot bacteria (Erwinia and Pseudomonas spp.), can cause problems whenever water accumulates on the developing broccoli head. Darling et al., (2000) found head rot resistance in broccoli is associated with smooth, domed heads and small, tight beads.

Black leg (Leptosphaeria maculans, formerly Phoma lingam) and Alternaria (caused by various Alternaria spp., but mainly $A$. brassicola) are two diseases that cause significant economic losses in Europe and eastern USA where pesticide based control options used by conventional growers are not available to organic growers (Lammerts van Bueren et al.,2002). Dixon (2007) recommended hot water treatment to disinfect the seed, but it is not completely reliable and may reduce germination. Resistance source have been observed among various Brassica species and needs to be transferred into $B$. oleracea background.

\section{Insect resistance}

Due to avoidance of insecticide applications under organic farming, organic growers has to follow alternative measures includes cultural management tools such as establishment of beetle banks to maintain high predator or parasite populations; companion plants to repel or distract pests; mass trapping systems, pheromone-based mating disruption and barrier-based approaches to control invertebrate pests (use of insect-proof net houses).

Many Brassica vegetables were grown under row covers to prevent cabbage fly infestation (Erioischia brassicae), flea beetle (Phyllotreta spp.) and lepidopteran pests (Plutella xylostella, Pieris rapae) during early season. Biological control products such as Bacillus thuringiensis and Spinosad are widely used to control lepidopteran pests (diamond back moth) and aphids. Plant 
phenotypes or morphological traits may positively or negatively associated with insect pest populations. Eigenbrode (1995) found glossy (waxless) variants of white head cabbage (B. oleracea) showed less damage from lepidopteran pests, reduced whitefly (Aleyrodes brassicae, Bemisia tabaci) populations and resulted in fewer eggs laid by cabbage maggots.

Moreover, the glossy phenotype also associated with reduced tissue damage from thrips. However, flea beetle damage was higher on glossy plants and both an increase and a decrease in aphid populations have been reported. Voorrips et al., (2008) observed a positive correlation between wax layer thickness and cabbage root fly infestation in white head cabbage and inferred that wax less trait would be best option in glasshouse production where only thrips and no other pests are predominant problem.

\section{Abiotic stress resistance/ tolerance}

Breeding for tolerance to abiotic stresses is another important issue. Apart from nutrient stress, drought, salinity, aluminium toxicity, cold and heat stress are other important abiotic stress factors that cause yield reductions (Witcombe et al., 2008). With climate change, the importance of drought and the area under saline soils are expected to increase significantly.

But, Breeding for drought and salinity tolerance has proved to be difficult (Blum, 2005) as the mechanisms of tolerance are very complex and poorly understood (Witcombe et al., 2008; Cattivelli et al., 2008; Ortiz et al., 2008). However, tolerance to abiotic stresses is important not only for organic but also for conventional agriculture. In some cases such as drought stress, organic farmers may give higher priority as they want to build up a system that is less dependent on inputs.

\section{Nutritive value or quality}

The demand for organic products is partially driven by the belief that organically grown products are healthier and more nutritious than conventionally grown products (Lotter, 2003). It is therefore plant breeder should consider the nutritional and quality parameters, while developing varieties for organic sector. Frossard et al., (2008) stated that significant variation in mineral and vitamin contents exists among varieties within crops and nutritional quality is often dependent on specific management practices. Similarly in broccoli, heterogeneity exists for important nutritional components (e.g. vitamin C, carotenoids, flavonoids and glucosinolates) and some breeding programmes has already selected for improving the contents of these nutritionally desirable compounds (Jeffery et al., 2003). The traits associated with tomato fruit quality depend very much on the market type. In general, higher levels of carotenoids (lycopene, $\beta$-carotene), vitamin $\mathrm{C}$ and flavonoids are considered beneficial. Tomatoes are a major source of carotenoids and vitamin $\mathrm{C}$ in the diet, but flavonoid content was fairly low compared to other vegetables. Jordan (2007) and Behrendt (2009) stated that flavour is one of the most difficult trait, tomato breeding programmes often include the selection steps designed to improve the tomato flavour. Tomato growers prefer good flavour, but cannot agree bad flavor, soft mealy texture, bland taste with low sugar content or a bad balance of sugar to acid ratio.

\section{Breeding approaches}

Over the last 40 years, organic farmers have mainly aimed at optimizing their farming systems by agronomic approaches. More and more the sector now also aims at genetic improvements to enhance yield stability under 
low-input conditions (Lammerts van Bueren et al., 2011). In vegetable sector, only a few organic farming focused breeding programmes have been started so far and farmers still largely depend on varieties bred for conventional, high-input farming systems. Although many breeding goals are identical for conventional and organic production, such as yield and disease resistance, the priorities can nevertheless be different. This is mainly due to the fact that conventional agriculture is able to compensate certain traits via inputs, including inorganic fertilizers and chemosynthetic crop protection chemicals that are not available for use in organic farming systems. Many traits desired for development of varieties suitable for organic and low-input farming systems should focuses on organic crop ideotype with overall yield stability and include morphological and physiological characteristics, such as plant and root architecture and vigour (Lammerts van Bueren et al., 2011). For leafy vegetables, it is important that they have the ability to grow in early spring conditions when the soil temperature is low. Hence, more attention needs to be paid to the development of a better root geometry (deeper and finer rooting system) with efficient water and nutrient uptake and the ability to maintain steady plant growth without stress under fluctuating water and nutrient availability. Furthermore, the organic sector demands breeding to focus on optimizing soil processes relevant for plant nutrition, soil fertility and crop disease resistance. Comparing to conventional farming systems, this implies a greater need for 'reliable' varieties, which means varieties with a greater flexibility to cope with such conditions. An essential element of organic farming is that it looks at agriculture as process based on a complex intertwining of agro-ecological, socio-economic and ethical principles. In addition, organic farmers are certified based on their farming process. Hence, organic farming looks at the breeding of new varieties in a holistic way. Thus, not only the varietal characteristics itself but also the process of varietal development must comply with the guiding principles of organic agriculture (Crespo and Ortiz, 2015).

As a consequence of rejecting certain breeding techniques like genetic engineering (GE) and techniques related to genetic engineering, appropriate breeding methods should be identified as a good alternative. The degree of overlap between varieties suitable for conventional and/or organic farming systems depends on the crop requirements and applied breeding techniques. In some specific crops, the problem to find suitable varieties that can perform well without high levels of mineral fertilizers and chemicalsynthetic fungicides, herbicides and pesticides is larger than for other crops. Cultivars for OA also need to have high weed competition or tolerance, high level of tolerance against soil and seed borne diseases and especially high requirements for shelf-life, as synthetic conservatives are not allowed. There is not only a need for varieties that fit in an organic system with good yield potential and nutritional quality but also that allow organic systems to work, meaning that the resilience of the whole farming system is supported and enhanced. Luby et al., (2013) argued that the organic sector has not yet reached its full potential until growers have access to regional adapted and organically bred varieties that balance yield with nutritional quality. According to Lammerts van Bueren et al., (2011), many of the selection approaches that are used in conventional breeding programmes can also be utilized in organic farming focused breeding programmes and were described hereunder.

\section{Sources of genetic diversity}

The creation and exploitation of genetic diversity is the main requirement for 
successful plant breeding. Breeders differentiate between the primary gene pool (elite breeding lines), secondary gene pool (landraces, lines not adapted to local conditions or gene bank material) and tertiary gene pool (related species or wild relatives). A vast unexploited genetic diversity is exist in all the vegetables which includes wild relatives, land races and germplasms/ accessions with biotic and abiotic stress (drought, high temperature, salinity, water logging and soil micronutrient imbalances) resistance/ tolerance was available and were not fully exploited. However, fair number of varieties and hybrids were developed by using the wild relatives.

Hence, the unexploited/untapped genetic variability available in the land races, wild relatives and germplasms /accessions may effectively utilized for development of varieties/ hybrids suitable for organic cultivation. Many vegetable varieties/ hybrids resistant to biotic and abiotic stress were developed using the wild recourses by public organizations and private companies. These may be utilized for organic cultivation without using plant protection chemicals. However, the package of practices may be optimized for organic cultivation of the same.

Exploiting genetic variation within the released varieties

Genetic variation within released varieties is relatively small in self-pollinated crops. An alternative method employed by Phillips and Wolfe (2005), maintaining genetic diversity and evolutionary fitness within varieties, is to create composite cross populations. Composite cross populations are formed by assembling seed stocks with diverse evolutionary origins and characteristics, recombination of these stocks by cross pollination, bulking of $F_{1}$ progenies and subsequent propagation of the bulked progenies in successive natural cropping environments. Natural selection takes place if more adapted genotypes produce more progenies than less adapted ones. Composite cross populations can provide dynamic gene pools, which in turn provide a means of conserving genetic resources in situ. They can also allow selection of heterogeneous crop varieties. According to Phillips and Wolfe (2005), composite cross populations may have the potential to allow evolutionary changes based on biotic and abiotic environmental interactions and might be an alternative for selecting superior pure lines especially for low input systems characterized by unpredictable stress conditions.

\section{Participatory plant breeding}

Participatory plant breeding (PPB) programmes originated in developing countries to meet the needs of low-input, small-scale farmers in marginal environments that are not targeted by commercial breeding companies (Ceccarelli et al., 2011). PPB involves breeders, farmers, as well as consumers, extension specialists, vendors, industry and rural co-operatives in plant breeding research.

It is termed 'participatory' because all stakeholders can influence all major stages of the breeding and selection process. These stakeholders become co-researchers as they can help to set overall goals, determine specific breeding priorities, make crosses, screen germplasm entries in the pre-adaptive phases of research, take charge of adaptive testing and lead the subsequent seed multiplication and diffusion process (Sperling et al., 2001).

Due to special need of farmers and small organic market not always being attractive for commercial plant breeders, this approach gained greater attention in breeding 
programmes for development of varieties suitable for organic farming systems (Dawson et al., 2008; Osman et al., 2008).

In conventional systems, inorganic fertilizers and synthetic crop protection chemicals often encourage homogeneity across a diversity of agro-environments. Organic and traditional low-input farms are often more heterogeneous and experience greater diversity of weed, pest and disease pressure and use more diverse rotational designs and soil management, tillage, fertilization and crop protection protocols.

To develop varieties suitable to these diverse agro-environments, Suneson recommended integration of evolutionary breeding with strong participatory selection components (Murphy et al., 2005 and Dawson et al., 2008).

This type of breeding strategy utilizes a combination of natural selection (survival and more progenies of the fittest genotype due to adaptation to local conditions) and farmer selection (active selection of genotypes that fit the defined breeding goals) to develop varieties with optimal adaptation to specific organic farming systems. Such integrated breeding approaches are known as evolutionary participatory breeding (EPB), which utilizes the skills and knowledge of both breeders and farmers to develop heterogeneous landrace populations and has demonstrated to be an effective breeding method for both traditional and modern farmers throughout the world (Dawson et al., 2008).

The Oregon State University (OSU) has developed few open pollinated (OP) broccoli varieties with similar productivity and quality traits available in F1 hybrids and suitable for organic production using a farmer participatory approach.

\section{Indirect phenotypic selection methods}

Some morphologic traits have been correlated with quantitative biotic or abiotic stress resistance. However, indirect selection for such morphological traits has not yet been widely implemented in plant breeding programmes (Lammerts van Bueren et al., 2011).

\section{Marker aided selection}

With the advent of molecular markers it became possible to dissect quantitatively inherited traits into single genes. A markerassisted breeding approach has been used to develop high-flavonoid tomato lines. More than $50 \%$ of the sequenced tomato genome has been assembled (http://sgn.cornell.edu/about/tomato sequencing.pl; accessed 23 March 2010) and as annotated sequence becomes available, it will be possible to identify and directly select candidate genes.

In some cases, the size of the organic market is too small to be economically attractive for professional breeding companies. Participatory approaches could represent an efficient alternative to develop new varieties for organic farming and should be further developed to reduce the reliance on commercial conventional farming focused breeding companies. However, more recently developed collaborative strategies involving both breeding companies and farmers and other supply chain stakeholder should also be encouraged to utilize commercial breeding expertise and facilities where this is possible.

This is an important opportunity not only to integrate farmers' and breeders' knowledge, but also the farmers' and breeders' eye. Finally, the introgression of traits urgently needed by the farmers to optimize organic farming systems and improve yield stability 
will also have a positive influence on conventional production systems that aim to reduce agrochemical input use while improving environmental impacts and longterm agricultural sustainability. Breeding for organic agriculture therefore deserves significantly more attention and support.

\section{References}

Anonymous. 2017. Organic-World.net: Information and background material on "The World of Organic Agriculture", edition 2017

APEDA Report.

2016. http://apeda.gov.in/apedawebsite/organic/ Organic_Products.htm.

Baresel J P, Zimmermann G and H J Reents. 2008. Effects of genotype and environment on $\mathrm{N}$ uptake and $\mathrm{N}$ partition in organically grown winter wheat (Triticum aestivum L.) in Germany. Euphytica 163: 347-354.

Behrendt U. 2009. Tomato breeding for taste by OldendorferSaatzucht, in: H. Oestergard, E.T. Lammerts van Bueren, L. BouwmanSmits (Eds.), Proceedings EucarpiaBioexploit Workshop on The Role of Molecular Marker Assisted Selection in Breeding Varieties for Organic Agriculture, Wageningen, The Netherlands, 25-27 February, 2009, Bioexploit Project, Wageningen-The Netherlands.

Berner A, Hildermann I, Fliessbach A, Pfiffner L, Niggli U and Mader P. 2008. Crop yield and soil fertility response to reduced tillage under organic management. Soil and Tillage Research 101: 89-96.

Bertin P and Gallais A. 2000. Genetic variation for nitrogen use efficiency in a set of recombinant maize inbred lines I. Agro physiological results. Maydica 45: 53-66.

Brandt K, Leifert C, Sanderson R and Seal C.J. 2011. Agro ecosystem Management and Nutritional Quality of Plant Foods: The Case of Organic Fruits and Vegetables. Crit. Rev. Plant Sci. 30: 177-197.
Carr PM, Horsley R D and Poland W W. 2003. Tillage and seeding rate effects on wheat cultivars: I. Grain production. Crop Science 43: 202-209.

Cattivelli L, Rizza F, Badeck F W, Mazzucotelli E, Mastrangelo A M, Francia E, Mare C, Tondelli A and Stanca A M. 2008. Drought tolerance improvement in crop plants: an integrated view from breeding to genomics. Field Crops Research 105: $1-14$.

Ceccarelli S, Grando S and Baum M. 2007. Participatory plant breeding in water limited environments. Experimental Agriculture 43: 411-435.

Cook R J. 2007. Management of resident plant growth-promoting rhizobacteria with the cropping system: A review of experience in the US Pacific Northwest. European Journal of Plant Pathology 119: 255-264.

Crespo H LA and Ortiz R. 2015. Plant breeding for organic agriculture: Something new? Agric Food Secur. 4: 25.

Crowder DW and Reganold J P. 2015. Financial competitiveness of organic agriculture on a global scale. Proc Natl Acad Sci. 112: 7611-7616.

Darling D, Harling R, Simpson R A, McRoberts $\mathrm{N}$ and Hunter E A. 2000. Susceptibility of broccoli cultivars to bacterial head rot: in vitro screening and the role of head morphology in resistance. European Journal of Plant Pathology 106: 11-17.

Dawson J C, Murphy KM and Jones S S. 2008. Decentralized selection and participatory approaches in plant breeding for lowinput systems. Euphytica, 160: 143-154.

Dixon G R. 2007. Vegetable brassicas and related crucifers, Crop Production Science in Horticulture Series, vol. 14, CABI, Wallingford, UK.

Donner D and Osman A. 2006. Handbook Cereal Variety Testing for Organic and Low Input Agriculture, COST860SUSVAR, Wageningen, Netherlands, Louis Bolk Institute, Driebergen, The Netherlands.

Eigenbrode S D and Espelie K E. 1995. Effects of plant epicuticular lipids on insect 
herbivores. Annual Review Entomology 40:171-194.

Fay PK and Duke WB. 1977. An assessment of allelopathic potential in Avena germplasm. Weed Science 25: 224-228.

FiBL statistics. 2015-16. www.fibl.org/en/themes/organic-farmingstatistics.html

Fliessbach A, Oberholzer H R, Gunst L and Mader P. 2007. Soil organic matter and biological soil quality indicators after 21 years of organic and conventional farming. Agriculture Ecosystems and Environment 118: 273-284.

Frossard E, Bucher M, Machler F, Mozafar A and Hurrell R. 2000. Potential for increasing the content and bioavailability of $\mathrm{Fe}, \mathrm{Zn}$ and $\mathrm{Ca}$ in plants for human nutrition. Journal of the Science of Food and Agriculture 80: 861-879.

Ghorani R, Wilcockson S, Koiocheki A and Leifert C. 2008. Soil management for sustainable crop disease control: A review. Environmental Chemistry Letters 6: 149-162.

Gosling P, Hodge A, Goodlass G and Bending G D. 2006. Arbuscular mycorrhizal fungi and organic farming. Agriculture, Ecosystems and Environment 113: 17-35.

Greenwood D J, Stellacci A M, Meacham M C, White P J and Broadley M R. 2006. Brassica cultivars: $\mathrm{P}$ response and fertilizer efficient cropping. Acta Horticulturae 700: 91-96.

Greenwood D J, Stellacci A M, Meacham M C, Broadley M R and White PJ. 2005. Phosphorus response components of different Brassica oleracea genotypes are reproducible in different environments. Crop Science 45: 1728-1735.

Hall T J. 1980. Resistance at the TMV locus in the tomato to tomato mosaic-virus. Euphytica 29: 189-197.

Hari Har Ram, 2012. Vegetable breeding principles and practices. Kalyani Publishers, New Delhi. (ISBN-139789327219463).

Hetrick BAD, Wilson GWT, Gill BS and Cox TS. 1995. Chromosome location of mycorrhizal responsive genes in wheat. Canadian Journal of Botany 73: 891897.

Horneburg B and Becker H. 2008. Does regional organic screening and breeding make sense? Experimental evidence from organic outdoor tomato breeding, in: Cultivating the Future Based on Science. 2nd Conference of the International Society of Organic Agriculture Research ISOFAR, Modena, Italy, 18-20 June, ISOFAR.

Itulya F M and Aguyoh J N. 1998. The effects of intercropping kale with beans on yield and suppression of redroot pigweed under high altitude conditions in Kenya. Experimental Agriculture 34: 171-176.

Jeffery E H, Brown AF, Kurilich A C, Keck A S, Matusheski N, Klein B P and Juvik J A. 2003. Variation in content of bioactive components in broccoli. Journal of Food Composition and Analysis 16: 323-330.

Jimenezosornio J J and Gliessman S R. 1987. Allelopathic interference in wild mustard (Brassica campestris L) and broccoli (Brassica oleracea L var. Italica) intercrop agro ecosystem, ACS Symposium Series 330: 262-274.

Jordan J A. 2007. The heirloom tomato as cultural object: investigating taste and space. Socio logia Ruralis 47: 20-41.

Kage H, Alt C and Stutzel S. 2003. Aspects of nitrogen use efficiency of cauliflower I. A simulation modelling based analysis of nitrogen availability under field conditions. Journal of Agricultural Science 141:1-16.

Kniss A R, Savage S D and Jabbour R. 2016. Corrections: Commercial crop yields reveal strengths and weaknesses for organic agriculture in the United States. PLoS ONE, 11: (PubMed: e0165851).

Kramer T. 1979. Environmental and genetic variation for protein content in winter wheat (Triticum aestivum L). Euphytica 28: 209-218.

Krauss M, Berner A, Burger D, Wiemken A, Niggli $U$ and Mader P. 2010. Reduced tillage in temperate organic farming: 
implications for crop management and forage production. Soil Use and Management 26: 12-20.

Kumar V, Mills D J, Anderson J D and Mattoo A K. 2004. An alternative agriculture system is defined by a distinct expression profile of select gene transcripts and proteins, Proceedings of the National Academy of Sciences of the United States of America 101: 10535-10540.

Lammerts van Bueren E T, Jones S S, Tamm L, Murphy K M, Myers J R, Leifert C and Messmer M M. 2011. The need to breed crop varieties suitable for organic farming, using wheat, tomato and broccoli as examples: A review. NJAS Wageningen Journal of Life Sciences 58: 193- 205.

Lammerts van Bueren E T, Struik P C and Jacobsen E. 2002. Ecological concepts in organic farming and their consequences for an organic crop ideotype. Netherlands Journal of Agricultural Science 50: 1-26.

Lammerts van Bueren E T, Struik P C and Jacobsen E. 2002. Ecological concepts in organic farming and their consequences for an organic crop ideotype, Netherlands,50: 1-26.

Lammerts van Bueren E T. 2003. Challenging new concepts and strategies for organic plant breeding and propagation. In Eucarpia Leafy Vegetables 2003 (eds. Th.J.L. van Hintum, A. Lebeda, D. Pink, J.W. Schut).

Larkan N J, Smith S E and Barker S J. 2007. Position of the reduced mycorrhizal colonization (Rmc) locus on the tomato genome map. Mycorrhiza 17: 311-318.

Lotter D W. 2003. Organic agriculture. Journal of Sustainable Agriculture, 21:59-128.

Luby C H, Lyon A H and Shelton A C. 2013. A New Generation of Plant Breeders Discovers Fertile Ground in Organic Agriculture. Sustainability 5:2722-2726.

Mader P, Edenhofer S, Boller T, Wiemken A and Niggli U. 2000. Arbuscularmycorrhizae in a long-term field trial comparing low-input (organic, biological) and high-input (conventional) farming systems in a crop rotation, Biology and Fertility of Soils 31: 150156.

Murphy K M, Campbell K G, Lyon S R and Jones S S. 2007. Evidence of varietal adaptation to organic farming systems. Field Crops Research 102:172-177.

Murphy K, Dawson J and Jones S S. 2008. Relationship among phenotypic growth traits, yield and weed suppression in spring wheat landraces and modern cultivars, Field Crops Research 105:107115.

Murphy K, Lammer D, Lyon S, Carter B and Jones S S. 2005. Breeding for organic and low-input farming systems: An evolutionary-participatory breeding method for inbred cereal grains. Renewable Agriculture and Food Systems $20: 48-55$.

Muthukumar P and Selvakumar, R. 2013. Glaustas Horticulture. New Vishal Publications. New Delhi. (ISBN 818399071-1)

Myers J R. 2009. Organic Seed Partnership Final Report. http://www.plbr. cornell.edu/psi/OSU\%20OSP\%20Final\% 20Report.pdf.

Nuijten E, Monika M M and Lammerts van Bueren E T. 2017. Concepts and Strategies of Organic Plant Breeding in Light of Novel Breeding Techniques. Sustainability 9(18): 1-19 (doi: 10.3390/su9010018).

Ortiz R, Braun H J, Crossa J, Crouch J H, Davenport G, Dixon J, Dreisigacker S, Duveiller E, He Z H, Huerta J, Joshi A K, Kishii M, Kosina P, Manes Y, Mezzalama M, Morgounov A, Murakami J, Nicol J, Ferrara G O, Ortiz-Monasterio J I, Payne T S, Pena R J, Reynolds M P, Sayre K D, Sharma R C, Singh R P, Wang J K, Warburton M, Wu H X and Iwanaga M. 2008. Wheat genetic resources enhancement by the International Maize and Wheat Improvement Center (CIMMYT), Genetic Resources and Crop Evolution, 55: 10951140. 
Osman A, Van den Brink L and Lammerts van Bueren E. 2014. Comparing organic and conventional testing for spring wheat in the Netherlands, in: International Federation of Organic Agriculture Movements (IFOAM). The IFOAM Norms; IFOAM: Bonn, Germany.

Ostergard $\mathrm{H}$, Finckh $\mathrm{M} \mathrm{R}$, Fontaine $\mathrm{L}$, Goldringer I, Hoad S P, Kristensen K, Lammerts van Bueren E T, Mascher F, Munki L and Wolfe M S. 2009. Time for a shift in crop production: embracing complexity through diversity at all levels. Journal of Science of Food and Agriculture 89:1439-1445.

Parvatha Reddy P. 2008. Organic farming for Sustainable Horticulture. Scientific Publishers (India). ISBN: 978-81-7233640-0.

Pelham J. 1966. Resistance in tomato to tobacco mosiac virus. Euphytica $15: 258-267$.

Phillips S L, Wolfe M S. 2005. Evolutionary plant breeding for low input systems, Journal of Agricultural Science 143: 245 254.

Ponisio L C, Monigle L K, Mace K C, Palomino J, Valpine P D and Kremen C. 2015. Diversification practices reduce organic to conventional yield gap. Proc. Biol. Sci. 282: 20141396.

Ponti D T, Rijk B and Van Ittersum M K. 2012. The crop yield gap between organic and conventional agriculture. Agric. Syst. 108: $1-9$.

Przystalski M, Osman A, Thiemt E M, Rolland B, Ericson L, Ostergard H, Levy L, Wolfe M, Büchse A and Piepho H P. 2008. Comparing the performance of cereal varieties in organic and non organic cropping systems in different European countries. Euphytica 163: 417-433.

Rao S C and Dao T H.1994. Straw quality of 10 wheat cultivars under conventional and no-till systems. Journal of Agronomy 86: 833-837.

Reganold J P and Wachter J M. 2016. Organic agriculture in the twenty-first century. Nat. Plants 2: 15221.

Renaud E C M, Van Bueren E L and Jiggins J.
2014. The Process of Interpreting and Implementing Organic Seed Regulation in the United States. Org. Agric. 4: 25-42.

Rengel Z and Marschner P. 2005. Nutrient availability and management in the rhizosphere: exploiting genotypic differences. New Phytologist. 168: 305312.

Seufert V L, Ramankutty $\mathrm{N}$ and Foley $\mathrm{J}$ A. 2012. Comparing the yields of organic and conventional agriculture. Nature 485: 229-232.

Shaharoona B, Naveed M, Arshad M, Zahir Z A. 2008. Fertilizer dependent efficiency of Pseudomonas for improving growth, yield and nutrient use efficiency of wheat (Triticum aestivum L.). Applied Microbiology and Biotechnology 79: 147-155.

Sharma A K. 2012. A handbook of organic farming. Agrobios (India). ISBN (13): 978-817754-099-4.

Sperling L, Ashby J A, Smith M E, Weltzien E and McGuire S. 2001. A framework for analyzing participatory plant breeding approaches and results. Euphytica 122: 439-450.

Stone A G, Scheuerell S J and Darby H M. 2004. Suppression of soil borne diseases in field agricultural systems: organic matter management, cover cropping and other cultural practices, in: F. Magdoff, R. Weil (Eds.), Soil Organic Matter in Sustainable Agriculture, CRC Press, Boca Raton. pp. 131-177.

Suneson C A. 1956. An evolutionary plant breeding method, Agronomy Journal.48: 188-191.

Tonguc $\mathrm{M}$ and Griffiths P D. 2004. Development of black rot resistant interspecific hybrids between Brassica oleracea L. cultivars and Brassica accession A 19182, using embryo rescue. Euphytica 136: 313-318.

Van Bruggen A H C and Finckh M R. 2016. Plant Diseases and Management Approaches in Organic Farming Systems. Annu. Rev. Phytopathol. 54: 25-54.

Van Bruggen A H C. 1995. Plant disease 
severity in high-input compared to reduced-input and organic farming systems. Plant Disease 79: 976-984.

Vaughn S F and Boydston R A. 1997. Volatile allelochemicals released by crucifer green manures. Journal of Chemical Ecology 23: 2107-2116.

Voorrips R E, Steenhuis B G, Tiemens H M and Van Bueren E T L. 2008. Plant traits associated with resistance to Thrips tabaci in cabbage (Brassica oleracea var capitata). Euphytica 163: 409-415.

Warman P R. 1998. Results of the long-term vegetable crop production trials: Conventional vs Compost amended soils. In: International Symposium on Composting and Use of Composted Materials for Horticulture 333-341.

Weisz R and Bowman D T. 1999. Influence of tillage system on soft red winter wheat cultivar selection, Journal of Production Agriculture 12: 415-418.

White P J. 2007. Nutrient Use Efficiency in
Brassica, http://www2.warwick. ac.uk/fac/sci/whri/ research/plant mineral nutrition/brassica/.

Wissuwa M, Mazzola M and Picard C. 2009. Novel approaches in plant breeding for rhizosphere related traits. Plant and Soil 321: 409-430.

Witcombe J R, Hollington P A, Howarth C J, Reader S and Steele K A. 2008. Breeding for abiotic stresses for sustainable agriculture. Philosophical Transactions of the Royal Society B-Biological Sciences 363: 703-716.

Wolfe M S, Baresel J P, Desclaux D, Goldringer I, Hoad S, Kovacs G, Loschenberger F, Miedaner T, Ostergard $\mathrm{H}$ and Lammerts van Bueren E T. 2008. Developments in breeding cereals for organic agriculture. Euphytica 163: 323346.

Wu H, Pratley J, Lemerle D and Haig T. 1999. Crop cultivars with allelopathic capability. Weed Research 39: 171-180.

\section{How to cite this article:}

Tamilselvi, N.A. and Arumugam, T. 2017. Breeding Approaches for Sustainable Vegetable Production - A Review. Int.J.Curr.Microbiol.App.Sci. 6(11): 2845-2860. doi: https://doi.org/10.20546/ijcmas.2017.611.336 